\title{
Concentrations of plasminogen activator inhibitor-1 (PAI-1) and urokinase plasminogen activator (uPA) in induced sputum of asthma patients after allergen challenge
}

\author{
Krzysztof Kowal, Marcin Moniuszko, Sebastian Zukowski, \\ Anna Bodzenta-Lukaszyk
}

Department of Allergology and Internal Medicine

\begin{abstract}
Urokinase plasminogen activator (UPA) and its inhibitor (PAI-1) are involved in tiisue remodeling and repair processes associated with acute and chronic inflammation. The aim of the study was to evaluate the effect of allergen challenge on concentration of uPA and PAI-1 in induced sputum of house dust mite allergic asthmatics (HDM-AAs). Thirty HDM-AAs and ten healthy persons (HCs)were recruited for the study. In 24 HDM-AAs bronchial challenge with Dermatophagoides pteronyssinus (Dp) and in 6 HDM-AAs sham challenege with saline were performed. In HDM-AAs sputum was induced 24 hours before $\left(\mathrm{T}_{0}\right)$ and 24 hours $\left(\mathrm{T}_{24}\right)$ after the challenge. Concentration of uPA and PAI-1 in induced sputum were determined using immunoenzymatic assays. At $\mathrm{T}_{0}$ in HDM-AAs mean sputum uPA (151 $\left.\pm 96 \mathrm{pg} / \mathrm{ml}\right)$ and PAI-1 $(4341 \pm 1262 \mathrm{pg} / \mathrm{ml})$ concentrations were higher than in $\mathrm{HC}(18.8 \pm 6.7 \mathrm{pg} / \mathrm{ml} ; \mathrm{p}=0.0002$ and $596 \pm 180 \mathrm{pg} / \mathrm{ml} ; \mathrm{p}<0.0001 ;$ for UPA and PAI-1 respectively). After allergen challenge further increase in sputum uPA (187 $\pm 144 \mathrm{pg} / \mathrm{ml} ; \mathrm{p}=0.03)$ and PAI-1 $(6252 \pm 2323 \mathrm{pg} / \mathrm{ml} ; \mathrm{p}<0.0001)$ concentrations were observed. Moreover, in Dp challenged, but not in saline challenged HDM-AAs the mean uPA/PAI-1 ratio decreased significantly at $\mathrm{T}_{24}$. No significant increase in the studied parameters were found in sham challenged patients. In HDM-AAs allergen exposure leads to activation of the plasmin system in the airways. Greater increase of the PAI-1 concentration than uPA concentration after allergen challenge may promote airway remodeling and play an important role in the development of bronchial hyperreactivity.
\end{abstract}

Key words: plasminogen activator inhibitor, urokinase, asthma, allergen challenge

\section{Introduction}

Airways of asthmatic patients are characterized by damage of airway epithelium and profound infiltrations of inflammatory cells including $\mathrm{T}$ cells, eosinophils, basophils and monocytes [1]. Some features of irreversible bronchial wall remodeling are also present, even in those with mild asthma [1]. The irreversible changes in the airway wall consist of increased deposition of extracellular matrix (ECM) proteins, hyperplasia and hypertrophy of smooth muscle cells, mucous cell metaplasia and increased number of blood vessels [1]. Progression of those changes

Correspondence: K. Kowal, Dept. of Allergology and Internal Medicine, Medical University of Bialystok,

Sklodowskiej-Curie Str. 24a, 15-276 Bialystok, Poland; tel.: (+4885) 7468373, fax.: (+4885) 7468601, e-mail: kowalkmd@umwb.edu.pl or kowalkmd@yahoo.pl is associated with loss of lung function and increased bronchial hyperreactivity [2]. Sensitization to house dust mite allergens is an independent risk factor for development of asthma [3]. In experimental studies exposure to house dust mite allergens leads to chronic airway inflammation with remodeling of airway wall and subsequent progressive airflow limitation [4].

Urokinase-type plasminogen activator (uPA) and plasminogen activator inhibitor-1 (PAI-1) play an important role in regulation of the inflammatory response and tissue remodeling [5,6]. In an animal asthma model either suppression of PAI-1 expression by knockout of the PAI-1 gene or delivery of exogenous uPA leads to decreased airway remodeling and decreased airway hyperresponsiveness [7-9]. In humans, genetic variants of $u P A$ and $P A I-1$ genes are associated with increased risk of allergic asthma [1015]. In clinically stable, mild allergic asthma patients elevated levels of uPA and PAI-1 in induced sputum 
have recently been demonstrated [16]. Moreover, allergen exposure leads to elevation of plasma PAI-1 concentration in allergic asthma patients [17]. It is not known wheather allergen exposure leads also to local (intrabronchial) upregulation of PAI-1 expression promoting in this way airway remodeling.

It was therefore of interest to evaluate the changes of UPA and PAI-1 in the airways of house dust mite allergic asthmatics (HDM-AAs) in response to allergen exposure.

\section{Methods}

Thirty HDM-AAs, eight house dust mite allergic nonasthmatic patients (HDM-ANAs) and ten nonactopic, healthy persons (HCs) were recruited for the study. The allergic asthmatic patients had recent episodes of dyspnea, cough and wheezing upon house dust exposure and had positive skin prick test results with house dust mite allergens, significant bronchoconstrictive response to inhaled histamine and positive bronchial allergen challenge. All patients who had received allergen immunotherapy or any antiasthma medication, (with the exception of short-acting beta-agonists used as needed) before the initial visit were not included in the study. The short acting beta agonists were withdrawn at least 2 days before the study. Other exclusion criteria included respiratory tract infection within 3 months before the study, smoking, or any systemic disease. In 24 HDM-AAs allergen bronchial challenge with Dermatophagoides pteronyssinus (Dp) extract, while in 6 HDM-AAs sham bronchial challenge with saline were performed.

Skin prick tests. All persons were skin tested using prick methodology with a screening panel of aeroallergens (Allergopharma, Reinbek, Germany) as described earlier [18].

Bronchial challenge. Histamine bronchial challenge was performed according to the method previously described elsewhere starting from a concentration of $0.62 \mathrm{mg} / \mathrm{ml}$ [18]. The procedure was continued until either at least $20 \%$ fall of $\mathrm{FEV}_{1}$ or histamine concentration $32 \mathrm{mg} / \mathrm{ml}$ was reached. Bronchial reactivity to histamine is expressed as histamine concentration causing $20 \%$ fall of $\mathrm{FEV}_{1}\left(\mathrm{PC}_{20}\right)$.

Bronchial provocation test with aqueous Dp extracts (Allergopharma, Germany) was performed according to the method previously described elsewhere [18]. In brief, patients inhaled five-fold increasing doses of allergen starting from a dose $0.8 \mathrm{SBE}$. Allergen inhalations were continued until either at least $20 \%$ fall of $\mathrm{FEV}_{1}$ or a cumulative dose $5000 \mathrm{SBE}$ was reached. Then $\mathrm{FEV}_{1}$ was measured every 15 minutes during the first hour, every 60 minutes during the next 11 hours and after 24 hours. Bronchial reactivity to $\mathrm{Dp}$ is expressed as Dp dose causing $20 \%$ fall of $\mathrm{FEV}_{1}\left(\mathrm{PD}_{20}\right)$.

Bronchial challenge with histamine or Dp allergen extract were performed only in HDM-AAs.

Exhaled nitric oxide measurements. Fractional exhaled nitric oxide (FeNO) concentration was evaluated "on-line" using a chemiluminescence analyzer $\mathrm{NOA}^{\mathrm{TM}} 280 \mathrm{i}$ (Sievers, USA). The measurements were performed according to the ATS recommendations as described before [19]. Briefly, each patient exhaled against the fixed expiratory resistance of $16 \mathrm{~cm} \mathrm{H}_{2} 0$, which resulted in a constant flow of $50 \mathrm{~mL} / \mathrm{s}$. Both $\mathrm{NO}$ concentration and flow rate were displayed on the screen. A plateau of NO concentration in the exhaled air at the selected exhalation rate was automatically selected by the computer software according to the ATS recommendations. The NO measurements were repeated 3 times and the mean value was used for analysis.
Sputum induction. Sputum was induced as described before [16]. Briefly, after premedication with $200 \mathrm{mcg}$ of salbutamol patients inhaled hypertonic saline solution ( 3 to $5 \% \mathrm{NaCl}$ ). The collected sputum volume was measured, mixed with an equal volume of $0.1 \%$ DTT (dithiotreitol) and than rocked at room temperature for 15 minutes. The samples were subsequently filtered through $0.42-\mu \mathrm{m}$ Millipore filter and centrifuged at $1500 \mathrm{~g}$ for 10 minutes. The supernatants were immediately aliquoted and frozen at $-70^{\circ} \mathrm{C}$ until further analysis. The pellets were resuspended in phosphatebuffered saline and total number of nonsquamous cells was assessed using Fuchs Rosenthal chamber. Sputum was induced 24 hours before allergen challenge $\left(\mathrm{T}_{0}\right)$ and 24 hours after allergen challenge $\left(T_{24}\right)$.

Biochemical and immunologic assays. Sputum PAI-1 and uPA concentrations were evaluated using enzyme-linked immunosorbent assays (Asserachrom, Diagnostica Stago, USA) according to the manufacturer's instruction as described before [16]. All samples were run in duplicates. Serum concentration of total IgE (tIgE) and allergen specific IgE (DpIgE) were evaluated using UnicCap (Phadia, Sweden).

Ethical issues. The study was approved by the local Ethics Committee (R-I-003/188/2005). All participants provided written informed consent.

Statistical analysis. Continuous variables were compared using the Student t-test. Fisher exact test was used to compare discrete parameters. Multiple regression analysis was used to determine relationship between quantitative parameters. Data for continuous variables were expressed as means with standard deviations. All computations were carried out using the Statistica software.

\section{Results}

There was no significant difference in gender distribution and age between HDM-AAs, HDM-ANAs and HC (Table 1). Patients with asthma were characterized by significantly lower lung function parameters and significantly elevated FeNO (Table 1). At $\mathrm{T}_{0}$, in HDM-AAs the mean sputum concentrations of uPA $(157 \pm 96 \mathrm{pg} / \mathrm{ml})$ and PAI-1 $(4398 \pm 1212 \mathrm{pg} / \mathrm{ml})$ were significantly greater than in $\mathrm{HCs}(23.8 \pm 6.7 \mathrm{pg} / \mathrm{ml} ; \mathrm{p}<0.0001$ and $566 \pm 189$ $\mathrm{pg} / \mathrm{ml} ; \mathrm{p}<0.0001$, for $\mathrm{uPA}$ and PAI-1 respectively) (Table 1). In HDM-ANAs, at $\mathrm{T}_{0}$, the mean concentration of uPA $(34.8 \pm 22.5 \mathrm{pg} / \mathrm{ml})$ and PAI- $1(821 \pm 387$ $\mathrm{pg} / \mathrm{ml})$ were significantly lower than in HDM-AAs $(\mathrm{p}=0.002$ and $\mathrm{p}<0.0001$; for $\mathrm{UPA}$ and PAI- 1 respectively). When HDM-AAs were stratified according to the type of asthmatic response to allergen challenge into those who responded with isolated early response (single responders - SRs) and those who responded with both early and late asthmatic responses (dual responders - DRs) no significant differences in the baseline lung function parameters eNO concentration, sputum cell counts, or sputum uPA and PAI-1 concentrations were demonstrated between SRs and DRs (Table 1). No significant difference in baseline uPA or PAI-1 sputum concentrations between the HDM-AAs subgroup challenged with $\mathrm{Dp}$ and that challenged with saline was demonstrated (Fig. 1). 
Table 1. Patients characteristics

\begin{tabular}{|c|c|c|c|c|c|c|c|c|}
\hline & $\begin{array}{c}\mathrm{HCs} \\
(\mathrm{n}=10)\end{array}$ & $\begin{array}{c}\text { IIDM- } \\
\text { AAs } \\
(\mathrm{n}=30)\end{array}$ & $\begin{array}{l}\text { IIDM- } \\
\text { ANAs } \\
(\mathrm{n}=8)\end{array}$ & $\begin{array}{c}\text { IICs } \\
\text { vs } \\
\text { HDM-AAs }\end{array}$ & $\begin{array}{l}\text { IICs vs } \\
\text { HDM- } \\
\text { ANAs }\end{array}$ & $\begin{array}{c}\text { SRs } \\
(\mathrm{n}=11)\end{array}$ & $\begin{array}{c}\text { DRs } \\
(\mathrm{n}=13)\end{array}$ & $\begin{array}{c}\text { SRs } \\
\text { vs } \\
\text { DRs }\end{array}$ \\
\hline$\Lambda \mathrm{gc}$ (ycars) & $27(18-40)$ & $28(21-38)$ & $27(21-35)$ & $\mathrm{p}^{-0.595}$ & $\mathrm{P}-0.62$ & $28(21-38)$ & $28(21-37)$ & $\mathrm{p}-0.68$ \\
\hline Sex (female/male) & $4 / 6$ & $13 / 17$ & $3 / 5$ & $\mathrm{p}=1.0$ & $\mathrm{P}=1.0$ & $5 / 6$ & $6 / 7$ & $\mathrm{p}=1.0$ \\
\hline $\mathrm{FEV}_{1}(\%$ predicted $)$ & $108 \pm 10.7$ & $95.1 \pm 14.1$ & $103.8 \pm 10.5$ & $\mathrm{p}=0.021$ & $\mathrm{P}=0.399$ & $97.7 \pm 18$ & $96.9 \pm 11.7$ & $\mathrm{P}=0.91$ \\
\hline $\mathrm{PC}_{20}(\mathrm{mg} / \mathrm{ml})$ & ND & $2,9+2.7$ & $>32$ & $\mathrm{~N} \Lambda$ & $\mathrm{N} \Lambda$ & $2.95+2.96$ & $3.23+3.0$ & $\mathrm{P}-0.73$ \\
\hline $\mathrm{PI}_{20}(\mathrm{SBF})$ & ND & $1515+1132$ & $>5000$ & NA & NA & $1628+1263$ & $1378+1070$ & $\mathrm{P}=0.61$ \\
\hline Exhaled NO (ppb) & $18 \pm 11$ & $107 \pm 71$ & $36 \pm 14$ & $\mathrm{p}=0.0004$ & $\mathrm{P}=0.008$ & $99.6 \pm 67$ & $113 \pm 91$ & $\mathrm{P}=0.69$ \\
\hline $\begin{array}{l}\text { Sputum cell count } \\
\left(\text { cells } \times 10^{6} / \mathrm{ml}\right)\end{array}$ & $1.7 \pm 1.2$ & $4.2 \pm 2.2$ & $2.4 \pm 0.7$ & $\mathrm{P}=0.0016$ & $\mathrm{P}=0.162$ & $4.15 \pm 1.64$ & $5.37 \pm 2.5$ & $\mathrm{P}=0.198$ \\
\hline Squamous cell count $(\%)$ & $4.2+0.9$ & $3.9+1.1$ & $3.75+0.71$ & $\mathrm{P}-0.44$ & $\mathrm{P}-0.266$ & $2.9+0.98$ & $2.31+0.95$ & $\mathrm{P}-0.14$ \\
\hline Sputum eosinophilia (\%) & $0.7 \pm 0.48$ & $5.97 \pm 2.24$ & $1.88 \pm 1.36$ & $\mathrm{P}<0.0001$ & $\mathrm{P}=0.02$ & $5.1 \pm 2.1$ & $6.4 \pm 2.6$ & $\mathrm{P}=0.22$ \\
\hline $\mathrm{uPA}(\mathrm{pg} / \mathrm{ml})$ & $23.8 \pm 6,7$ & $157 \pm 96$ & $34.8 \pm 22.5$ & $\mathrm{P}=0.0001$ & $\mathrm{P}=0.159$ & $118 \pm 50$ & $176 \pm 117$ & $\mathrm{P}=0.156$ \\
\hline $\mathrm{P} \wedge \mathrm{I}-1(\mathrm{pg} / \mathrm{ml})$ & $566+189$ & $4398+1212$ & $821+387$ & $\mathrm{P}-0.0001$ & $\mathrm{P}-0.074$ & $4200+1157$ & $4450+1374$ & $\mathrm{P}-0.648$ \\
\hline
\end{tabular}

At $\mathrm{T}_{24}$ increase in sputum PAI-1 concentration was seen in all (100\%) HDM-AAs challenged with Dp allergen, but only in 2 out of $6(33.3 \%)$ sham challenged HDM-AAs $(p=0.0006)$ and in 4 out of $8(50 \%)$ Dp challenged HDM-ANAs ( $\mathrm{p}=0.002$ vs HDM-AAs). Sputum uPA increased in 16 out of 24 (66.7\%) HDM-AAs challenged with $\mathrm{Dp}$, in 2 out of $6(33.3 \%)$ sham challenged HDM-AAs $(\mathrm{p}=0.184)$ and in 4 out of $8(50 \%)$ Dp challenged HDM-ANAs ( $\mathrm{p}=0.43$ vs HDM-AAs). In HDMAAs challenged with $\mathrm{Dp}$ significant increase in the mean sputum PAI-1 from $4342 \pm 1263 \mathrm{pg} / \mathrm{ml}$ at $\mathrm{T}_{0}$ to $6252 \pm 2324 \mathrm{pg} / \mathrm{ml}$ at $\mathrm{T}_{24}(\mathrm{p}<0.0001)$ was observed. Neither in sham challenged HDM-AAs $(4616 \pm 1071 \mathrm{pg} / \mathrm{ml}$ at $\mathrm{T}_{0}$ and $4571 \pm 837 \mathrm{pg} / \mathrm{ml}$ at $\left.\mathrm{T}_{24} ; \mathrm{p}=0.759\right)$ nor in HDM-ANAs challenged with Dp (34.8 $22.5 \mathrm{pg} / \mathrm{ml}$ at $\mathrm{T}_{0}$ and $40.5 \pm 28.5 \mathrm{pg} / \mathrm{ml}$ at $\mathrm{T}_{24} ; \mathrm{p}=0.65$ ) significant change in the mean sputum PAI-1 concentration after the allergen challenge was demonstrated. In Dp challenged HDM-AAs significant increase in the mean sputum uPA concentration from $151 \pm 96 \mathrm{pg} / \mathrm{ml}$ at $\mathrm{T}_{0}$ to $187 \pm 144 \mathrm{pg} / \mathrm{ml}$ at $\mathrm{T}_{24}(\mathrm{p}=0.033)$ was seen but neither in sham challenged HDM-AAs $\left(179 \pm 99 \mathrm{pg} / \mathrm{ml}\right.$ at $\mathrm{T}_{0}$ and $168 \pm 87 \mathrm{pg} / \mathrm{ml}$ at $\mathrm{T}_{24} ; \mathrm{p}=0.152$ ) nor in Dp challenged HDM-ANAs $\left(821 \pm 387 \mathrm{pg} / \mathrm{ml}\right.$ at $\mathrm{T}_{0}$ and $875 \pm 406 \mathrm{pg} / \mathrm{ml}$ at $\mathrm{T}_{24} ; \mathrm{p}=0.79$ ) significant difference in mean sputum uPA concentration was demonstrated. Among HDMAAs significant increase in PAI-1 concentration was seen in both $\mathrm{SR}\left(6143 \pm 2151 \mathrm{pg} / \mathrm{ml}\right.$ at $\left.\mathrm{T}_{24} ; \mathrm{p}=0.007\right)$ and in DR $\left(6336 \pm 2532 \mathrm{pg} / \mathrm{ml}\right.$ at $\left.\mathrm{T}_{24} ; \mathrm{p}=0.0003\right)$, but significant increase in uPA concentration was seen only in DR $\left(244 \pm 161 \mathrm{pg} / \mathrm{ml}\right.$ at $\left.\mathrm{T}_{24} ; \mathrm{p}=0.01\right)$ but not in SR $(135 \pm 103$ $\mathrm{pg} / \mathrm{ml}$ at $\left.\mathrm{T}_{24} ; \mathrm{p}=0.3\right)$. After the challenge the mean uPA/PAI-1 ratio decreased significantly in Dp challenged HDM-AAs, but did not change significantly in those challenged with saline (Fig. 2). The changes of sputum PAI-1 concentration after allergen challenge significantly, inversely correlated with baseline $\mathrm{FEV}_{1}$ and $\log _{\mathrm{PC} 20}(\mathrm{r}=-0.636 ; \mathrm{p}=0.0008$ and $\mathrm{r}=-0.878$; $\mathrm{p}<0.0001$ respectively) (Fig. 3.). The changes of uPA concentration after the challenge did not correlate with $\mathrm{FEV}_{1}$ or $\log _{\mathrm{PC} 20}$ but correlated with the change in sputum total cell count number $(r=0.627 ; p=0.0014)$ and with percentage of eosinophils in induced sputum $(\mathrm{r}=0.645 ; \mathrm{p}=0.0009)$ (not shown).

\section{Discussion}

This study supports previous observations linking the plasmin system with pathogenesis of allergic asthma [816]. In the present study we demonstrate that, in the airways of allergic asthma patients, allergen exposure leads to up-regulation of both components of the plasmin system: PAI-1 and uPA. Moreover, 24 hours after the challenge, which corresponded to the time point when resolution mechanisms are already in progress, increase in sputum PAI-1 concentration considerably exceeded that of uPA. This also holds true when the molar concentrations of PAI- 1 and UPA are compared. Since the stoichiometry of PAI- 1 and UPA in the PAI-1uPA inactive complex is $1: 1$, it can be assumed that at $\mathrm{T}_{24}$ the inhibitory potential of PAI-1 exceeds the proteolytic activity of uPA. Interestingly, in individual patients, the increase of PAI-1 concentration 24 hours after allergen challenge was greater than the total uPA concentration at that time point suggesting that even the newly generated PAI-1 can potentially neutralized the whole uPA activity in the sputum at $\mathrm{T}_{24}$. Increasing body of evidence indicates that the predominance of PAI-1 inhibitory effects promotes irreversible tissue remodeling. In mice overexpressing PAI-1, intratracheal administration of bleomycin resulted in increased fibrosis [20]. On the contrary, pulmonary fibrosis in response 


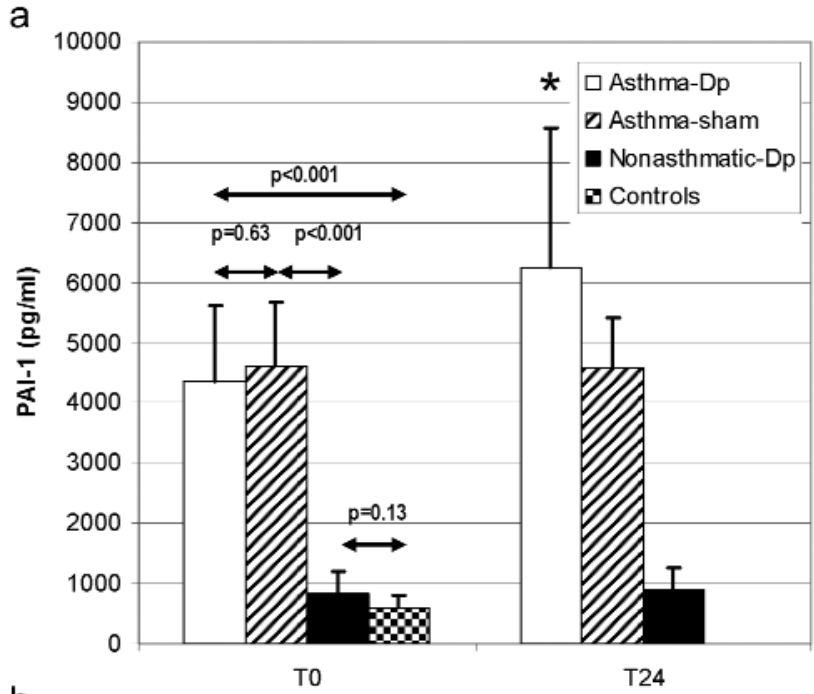

b

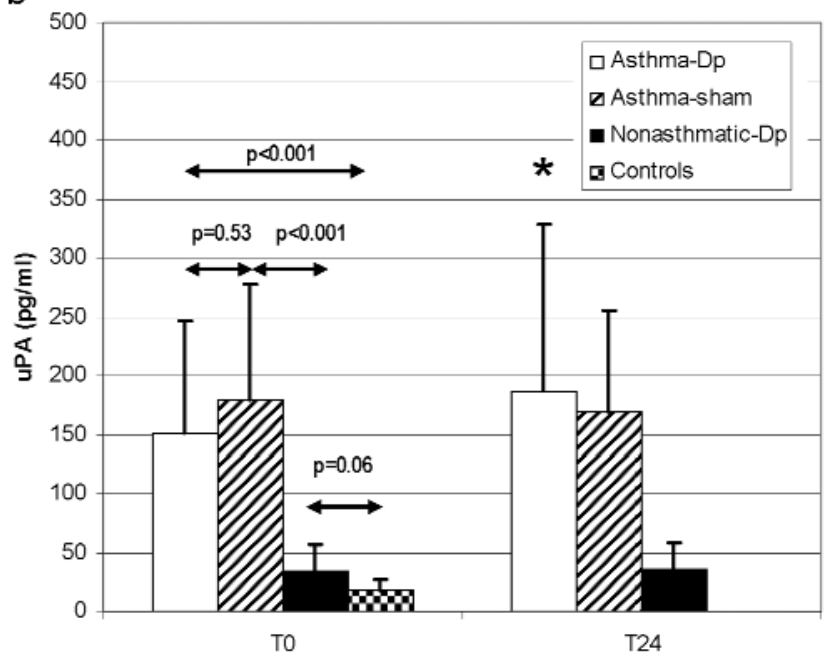

Fig. $1 \mathrm{a}$ and $\mathrm{b}$ Sputum PAI-1 and uPA concentration before $\left(\mathrm{T}_{0}\right)$ and after $\left(\mathrm{T}_{24}\right)$ allergen challenge. ${ }^{*}$ - significantly greater in comparison with $\mathrm{T} 0$.

to bleomycin is significantly attenuated in PAI-1 knockout mice. Similarly, in PAI-1 deficient mice sensitized to ovalbumin (OVA) attenuation of extracellular matrix deposition in response to OVA inhalation was demonstrated [8]. The association between Dp induced upregulation of PAI-1 in the airways and airway remodeling is further supported by highly significant correlations between the allergen induced changes in sputum PAI-1 concentration and baseline $\mathrm{FEV}_{1}$ or bronchial reactivity. This may, at least partially, explain why repeated exposure to dust mite allergens in sensitized patients may lead to increased bronchial hyperreactivity. Unfortunately we are not able to reveal mechanisms leading to greater upregulation of PAI-1 expression in some of the studied patients. Association between genetic predisposition to greater PAI-1 synthesis and asthma or bronchial reactivity demonstrated in the previous studies indicates that genetic factor(s) may be involved in
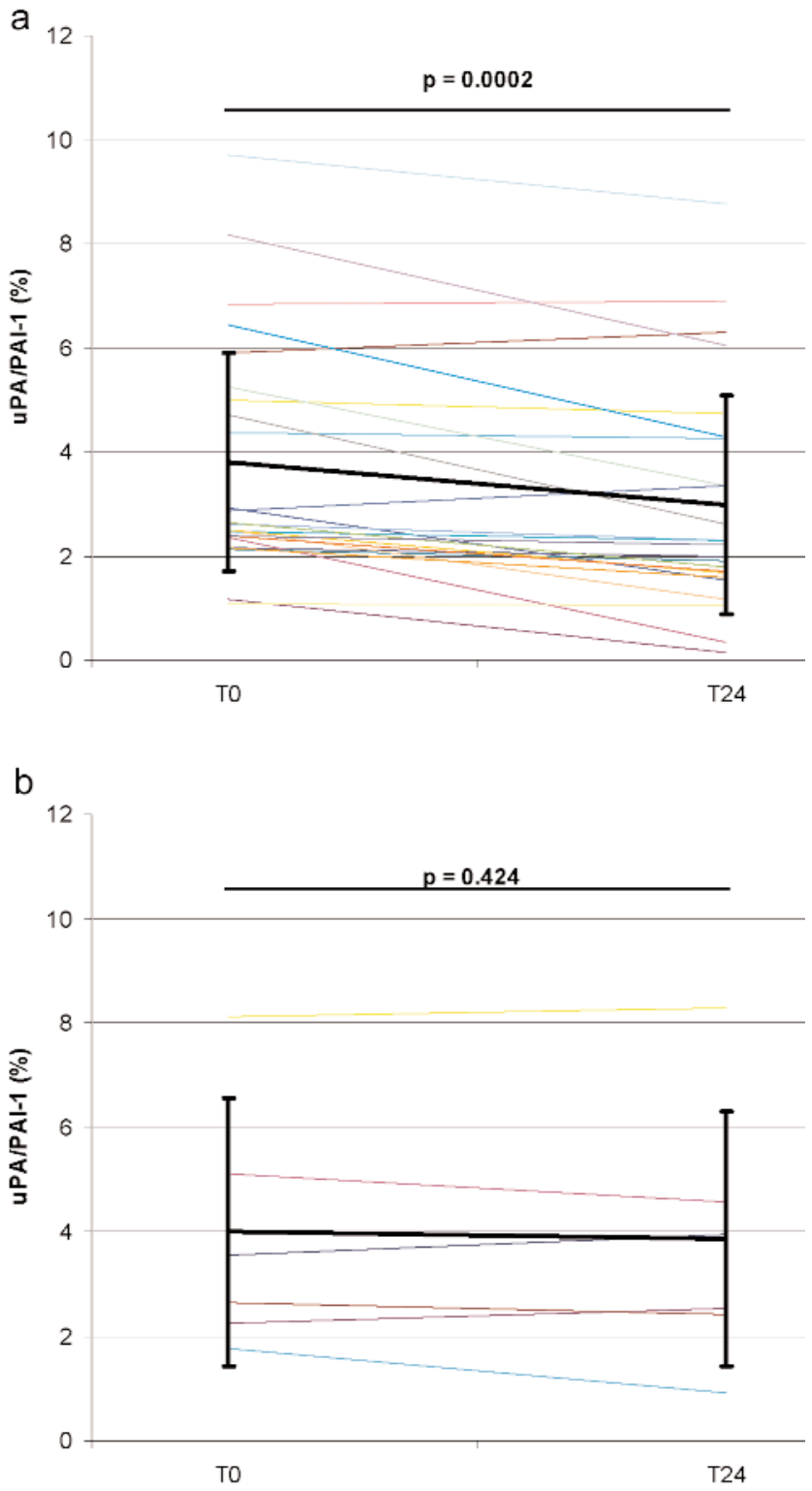

Fig. 2 a and b. Changes in the ratio uPA/PAI-1 concentration in induced sputum before and after Dp challenge (a) and sham challenge (b).

this processes.

Allergen exposure is associated with increased plasma PAI-1 concentration [17]. Plasma exudate from microvascular leakage during asthmatic response may lead to efflux of PAI-1 into airways. However, it seems that plasma is not the predominant source of sputum PAI-1 because elevated sputum levels of PAI-1 are still observed 24 hours after the challenge, while at that time point plasma levels within the circulation return to baseline values [17]. Synthesis of both PAI-1 and uPA is rapidly induced by many factors including cytokines, growth factors and hormones [5,6]. Several potential sources of PAI- 1 and UPA in the airways of asthmatic patients have to be considered. The main 


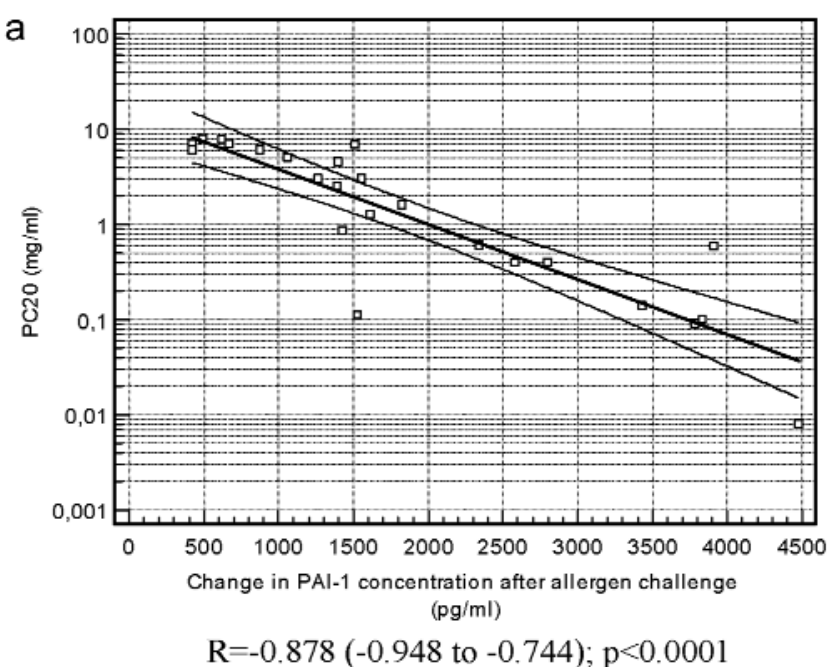

C

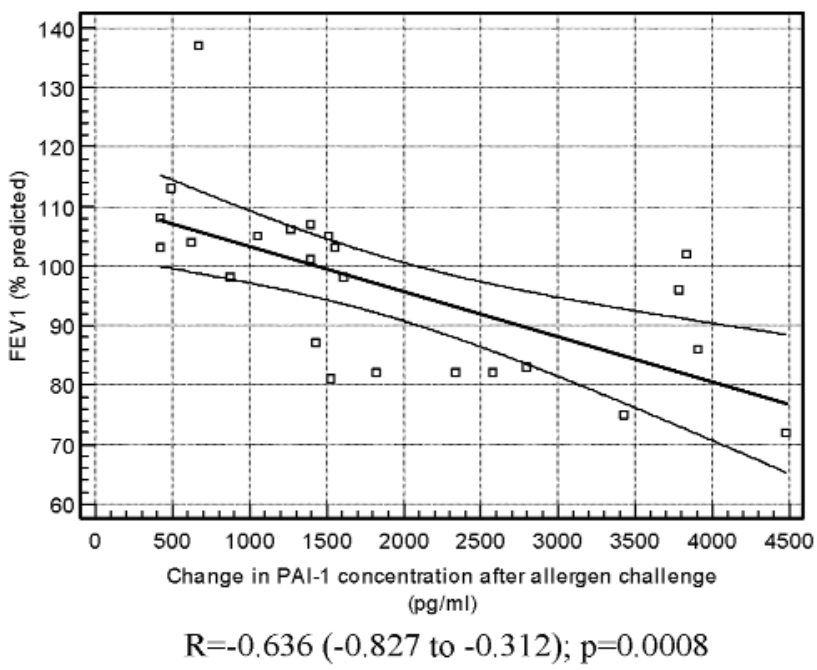

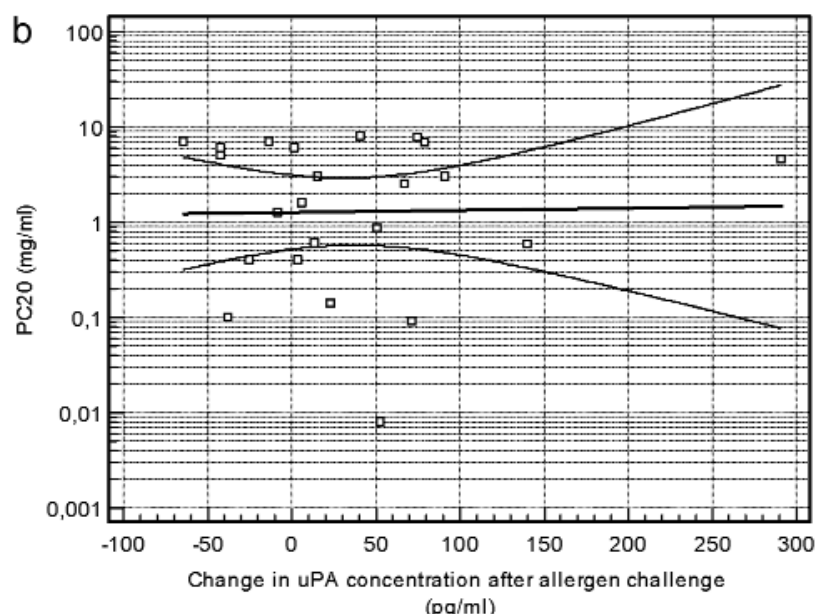

$(\mathrm{pg} / \mathrm{ml})$

d

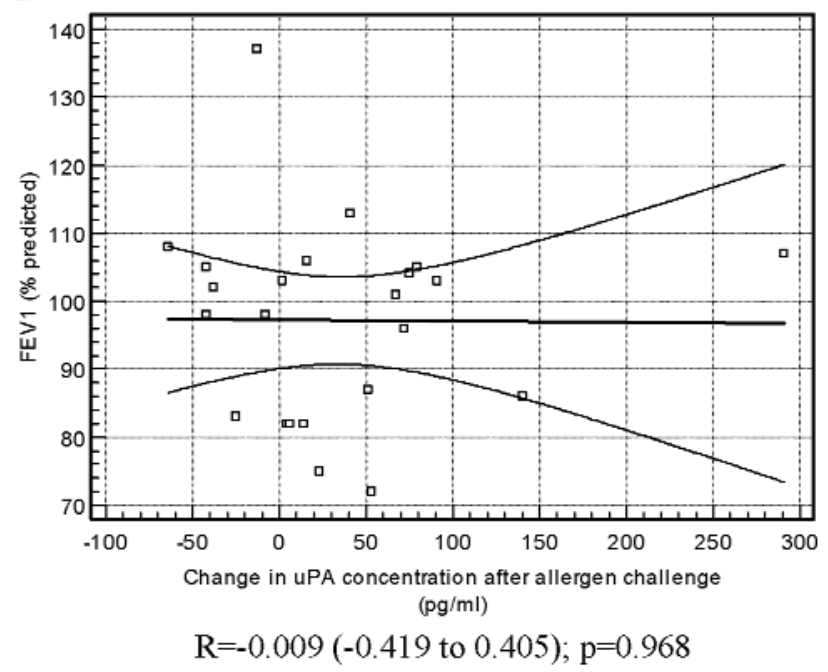

Fig. 3 a-d. Correlations between the change in sputum PAI-1 (a and c) or uPA (b and d) concentrations and baseline bronchial reactivity expressed as $\log \mathrm{PC}_{20}$ (a and b) or baseline $\mathrm{FEV}_{1}$ (c and d).

cells responsible for production of plasminogen activators are endothelial cells, fibroblasts, mast cells, monocytes/macrophages, smooth muscle cells and epithelial cells, while plasmin system inhibitors are synthesized by endothelium, platelets and megakaryocytes, neutrophils, monocyte/macrophages, eosinophils, smooth muscle cells, fibroblasts and epithelial cells $[5,21,22]$. Interestingly, activated mast cells can secrete PAI-1, while activated T cells synthesize uPA $[23,24]$. Bronchial epithelial cells, which make up an interface between outer and inner environments, have been shown to release both PAI-1 and uPA $[25,26]$. Several exogenous and endogenous factors induce PAI-1 and uPA synthesis by bronchial epithelial cells [25-27]. Even mechanical stimulation induces expression of all components of the plasmin system in cultured bronchial epithelial cells [27]. Similarly, in ovalbumin sensitized mice allergen exposure leads to enhanced PAI-1 expression in bronchial epithelial cells
[22] Moreover, human bronchial epithelial cells can be activated by enzymatically active and non-enzymatic house dust mite allergens.

In an animal asthma model chronic allergen exposure is associated with airway remodeling and bronchial hyperreactivity [22]. Some features of airway remodeling were seen long after cessation of allergen exposure, which indicates that in sensitized animals prolonged allergen exposure may lead to chronic asthma phenotype. Intratracheal administration of exogenous uPA in OVA sensitized and exposed to OVA mice leads to amelioration of airway remodeling and airway hyperresponsiveness [9]. In humans, genetic predisposition for augmented PAI-1 synthesis, caused by the presence of $4 \mathrm{G}$ allele in the position -675 of the PAI- 1 gene, is associated with enhanced bronchial reactivity and decreased lung function [11-15]. Elevated levels of PAI-1 in sputum of asthmatic patients has also been reported $[16,28]$. The exact role of genetic predisposition 
and environmental factors in activation of the plasmin system in the airways has to be determined.

In summary, our study demonstrates that in Dp sensitized asthmatic patients allergen exposure leads to local activation of the plasmin system in the airways, with predominant anti-proteolytic effects delivered by overwhelming increase of PAI-1 release. Further studies are warranted to determine mechanisms which lead to activation of plasmin system in response to allergen exposure.

Acknowledgments: This work was supported by a grant from Medical University of Bialystok research grants 3-35493 (KK and AB-L)

\section{References}

[1] Busse W, Elias J, Sheppard D, Banks-Schelegel A. Airway remodeling and repair. Am J Respir Crit Care Med. 1999; 160:1035-42.

[2] Chetta A, Foresi A, Del Donno M, Bertorelli G, Pesci A, Olivieri D. Airway remodeling is a distinctive feature of asthma and is related to severity of asthma. Chest. 1997;111:852-7.

[3] Global Strategy for Asthma Management and Prevention. NIH publication No 02-365P. Revised 2002.

[4] Johnson JR, Wiley RE, Fattouh R et al. Continuous exposure to house dust mite elicits chronic airway inflammation and structural remodeling. Am $J$ Respir Crit Care Med. 2004;169:378-85.

[ 5] Kucharewicz I, Kowal K, Buczko W, Bodzenta-Lukaszyk A. The plasmin system in airway remodeling. Thromb Res. 2003;112:1-7.

[ 6] Ma Z, Paek D, Oh CK. Plasminogen activator inhibitor-1 and asthma: role in the pathogenesis and molecular regulation. Clin Exp Allergy. 2009;39:1136-44.

[7] Sejima T, Madoiwa S, Mimuro J, Sugo T, Okada K, Ueshima $\mathrm{S}$ et al. Protection of plasminogen activator inhibitor-1-deficient mice from nasal allergy. J Immunol. 2005;174:8135-43.

[ 8] Oh CK, Ariue B, Alban RF, Shaw B, Cho SH. PAI-1 promotes extracellular matrix deposition in the airways of a murine asthma model. Biochem Biophys Res Commun. 2002;294:1155-60.

[9] Kuramoto E, Nishiuma T, Kobayashi K, Yamamoto M, Kono Y, Funada Y, Kotani Y et al. Inhalation of urokinase-type plasminogen activator reduces airway remodeling in a murine asthma model. Am J Physiol Lung Cell Mol Physiol. 2009;296:L337-46.

[10] Begin P, Tremblay K, Daley D, Lamire M, Claveau S et al. Association of urokinase-type plasminogen activator with asthma and atopy. Am J Respr Crit Care Med. 2007; 175:1109-16.

[11] Cho SH, Hall IP, Wheatley A, Dewar J, Abraha D, Del Mundo $\mathrm{J}$ et al. Possible role of the $4 \mathrm{G} / 5 \mathrm{G}$ polymorphism of the plasminogen activator inhibitor 1 gene in the development of asthma. J Allergy Clin Immunol. 2001;108:212-14.

[12] Buckova D, Izakovicova Holla L, Vacha J. Polymorphism $4 \mathrm{G} / 5 \mathrm{G}$ in the Plasminogen activator inhibitor-1 (PAI-1) gene is associated with IgE-mediated allergic diseases and asthma in the Czech population. Allergy. 2002;57:446-8.

[13] Pampuch A. Kowal K, Bodzenta-Lukaszyk A, Di Castelnuovo A, Chyczewski L, Donati MB, Iacoviello L. The -675 4G/5G plasminogen activator inhibitor-1 promoter polymorphism in house dust mite-sensitive allergic asthma patients. Allergy. 2006;61:234-8.

[14] Kowal K, Bodzenta-Lukaszyk A, Pampuch A, Szmitkowski
M, Zukowski S, Donati MB, Iacoviello L. Analysis of -675 4G/5G SERPINE1 and C-159T CD14 polymorphisms in house dust mite-allergic asthma patients. $J$ Investig Allergol Clin Immunol. 2008;18:284-92.

[15] Ozbek OY, Atac FB, Ogus E, Ozbek N. Plasminogen activator inhibitor-1 gene $4 \mathrm{G} / 5 \mathrm{G}$ polymorphism in Turkish children with asthma and allergic rhinitis. Allergy Asthma Proc. 2009;30:41-6.

[16] Kowal K, Zukowski S, Moniuszko M, Bodzenta-Lukaszyk A. Plasminogen activator inhibitor-1 (PAI-1) and urokinase plasminogen activator (uPA) in sputum of allergic asthma patients. Folia Histochem Cytobiol. 2008;46:193-8.

[17] Kowal K, Bodzenta-Lukaszyk A, Pampuch A, Szmitkowski $\mathrm{M}$, Donati MB, Iacoviello L. Plasminogen activator inhibitor1 (PAI-1) plasma concentration in allergic asthma patients during allergen challenge. Int Arch Allergy Immunol. 2007; 144:240-6.

[18] Kowal K, Osada J, Zukowski S, Dabrowska M, DuBuske LM, Bodzenta-Lukaszyk A. Expression of interleukin-4 receptor in bronchial asthma patients treated with specific immunotherapy (SIT). Ann Allergy Asthma Immunol. 2004;93:68-75.

[19] Kowal K, Moller HJ, DuBuske LM, Moestrup SK, BodzentaLukaszyk A. Differential expression of monocyte CD163 in single- and dual-asthmatic responders during allergeninduced bronchoconstriction. Clin Exp Allergy. 2006;36:1584-91.

[20] Eitzman DT, McCoy RD, Zheng X, Fay WP, Shen T, Ginsburg D, Simon RH. Bleomycin-induced pulmonary fibrosis in transgenic mice that either lack or overexpress the murine plasminogen activator inhibitor-1 gene. J Clin Invest. 1996;97:232-7.

[21] Kucharewicz I, Mogielnicki A, Kasacka I, Buczko W, Bodzenta-Lukaszyk A. Plasmin system regulation in an ovalbumin-induced rat model of asthma. Int Arch Allergy Immunol. 2008;147:190-6.

[22] Kelly MM, Leigh R, Bonniaud P, Ellis R, Wattie J, Smith MJ et al. Epithelial expression of profibrotic mediators in a model of allergen-induced airway remodeling. Am J Respir Cell Mol Biol. 2005;32:99-107.

[23] Cho SH, Tam SW, Demissie-Sanders S, Filler SA, Oh CK. Production of plasminogen activator inhibitor-1 by human mast cells and its possible role in asthma. J Immunol. 2000;165:3154-61.

[24] Gunderson D, Tran-Thang C, Sordat B, Mourali F, Ruegg C. Plasmin induced proteolysis of tenascin-C: modulation by $\mathrm{T}$ lymphocyte-derived urokinase-type plasminogen activator and effect on $\mathrm{T}$ lymphocyte adhesion, activation, and cell clustering. J Immunol. 1997;158:1051-60.

[25] Shetty S, Bdeir K, Cines DB, Idell S. Induction of plasminogen activator inhibitor-1 by urokinase in lung epithelial cells. J Biol Chem. 2003;278:18124-31.

[26] Marshall BC, Xu QP, Rao NV, Brown BR, Hoidal JR. Pulmonary epithelial cell urokinase-type plasminogen activator. Induction by interleukin- $1 \beta$ and tumor necrosis factor- $\alpha$.

[27] Chu EK, Cheng J, Foley JS, Mecham BH, Owen CA, Haley $\mathrm{KJ}$, et al. Induction of the plasminogen activator system by mechanical stimulation of human bronchial epithelial cells. Am J Respir Cell Mol Biol. 2006;35:628-38.

[28] Ciao W, Hsu YP, Ishizaka A, Kirikae, Moss RB. Sputum cathelicidin, urokinase plasminogen system components and cytokine discriminate cystic fibrosis, COPD and asthma inflammation. Chest. 2005;128:2316-26.

Submitted: 16 August, 2010 Accepted after reviews: 8 September, 2010 